\title{
250692
}

DP-MS-87-70

\section{LEACHING TC-99 FROM SRP GLASS IN SIMULATED TUFF AND SALT GROUNDWATERS}

by

N. E. Bibler and A. R. Jurgensen

E. I. du Pont de Nemours \& Co.

Savannah River Laboratory

Aiken, South Carolina 29808

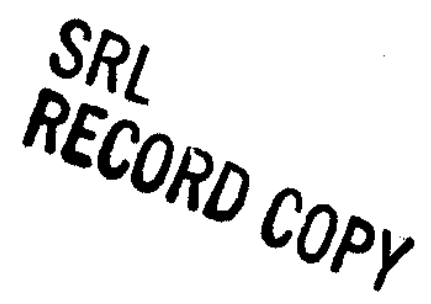

A paper for presentation at the Materials Research Society XI International Symposium

on the Scientific Basis for Nuclear Waste Management .

Boston, Massachussetts

November 30 - December 5, 1987

and for publication in the Proceedings

This paper was prepared in connection with work done under Contract No. DE-AC09-76SR00001 with the U.S. Department of Energy. BY acceptance of this paper, the publisher and/or recipient acknowledges the U.S. Government's right to retain a nonexclusive, royalty-free license in and to any copyright covering this paper, along with the right to reproduce and to authorize others to reproduce all or part of the copyrighted paper. 


\title{
LEACHING TC-99 FROM SRP GLASS IN \\ SIMULATED TUFF AND SALT GROUNDWATERS*
}

\author{
N. E. BIBLER and A. R. JURGENSEN \\ E. I. du Pont de Nemours \& Co., Savannah River Laboratory, \\ Aiken, SC 29808
}

\section{ABSTRACT}

Results of leach tests with Tc-99 doped SRP borosilicate waste glass are presented. The glass was prepared by melting a mixture of SRP 165 powdered frit doped with a carrier free solution of Tc-99 at $1150^{\circ} \mathrm{C}$. Dissolution of portions of the resulting glass indicated that the Tc-99 was distributed homogeneously throughout the glass. Static leach tests up to 90 days were performed at $90^{\circ} \mathrm{C}$ in J-13 tuff groundwater or WIPP brine $A$ at a SA/V of $100 \mathrm{~m}^{-1}$. Normalized mass losses were calculated for Tc-99 as well as all the major elements in the glass. Results indicated that under ambient oxidizing conditions Tc-99 leached no faster than the glass-forming elements of the glass. In J-13 water, Tc-99 leached congruently with B. In WIPP brine $\mathrm{A}$, it leached congruently with $\mathrm{Si}$. Leach rates for $\mathrm{Li}$ were higher in both groundwaters, probably due to a contribution from an ion exchange mechanism. Leach tests were performed under reducing conditions in $\mathrm{J}-13$ water by adding $\mathrm{Zn} / \mathrm{Hg}$ amalgam to the leachate. In these tests the $\mathrm{pH}$ increased significantly, probably because of the reaction of the amalgam with the water. In a 21-day test, the $\mathrm{pH}$ increased to 13 and leach rates for the glass were very high. Even though there was significant dissolution of the glass, the normalized mass loss based on Tc-99 was only $0.02 \mathrm{~g} / \mathrm{m}^{2}$. This result and the fact that reducing conditions at normal $\mathrm{pH}$ values do not significantly affect the dissolution of the glass, indicate that the low concentrations for Tc-99 obtained under reducing conditions are due to its solubility and not due to an increased durability of the glass.

\section{INTRODUCTION}

Technetium-99 (Tc-99) is a beta emmitting fission product in the high level radioactive waste stored at Savannah River Plant (SRP). Because its long half-life $\left(\mathrm{T}_{1 / 2}=2.13 \times 10^{5}\right.$ years), and its high solubility in geologic groundwaters as the pertechnetate anion, $\mathrm{TcO}_{4}{ }^{-}$, Tc-99 is of special concern in the geologic storage of nuclear waste glass.

The purpose of the tests described in this paper was to determine whether borosilicate glass simlilar to that which will be produced in the Defense Waste Processing Facility (DWPF) at SRP will immobilize Tc-99 as well as it does other elements. A previous study[1] (using a borosilicate glass of a different composition from DWPF glass) indicated that Tc-99 leached very rapidly from the glass; this suggested that glass may not be a good matrix for immobilizing Tc-99. It was also suggested [1] that the Tc-99 had migrated to vesicles in the glass while the glass was still molten.

Another purpose of this study was to compare the normalized release of Tc-99 under oxidizing and reducing conditions with that of other elements in the glass. Other studies [2,3] had shown that reducing conditions significantly decreased the amount of Tc-99 in solution. In those studies, only solution concentrations were presented; thus, it was difficult to determine if the lower Tc-99 concentrations were due to the glass leaching less or to the reduction of Tc-99 to the $4+$ state which formed $\mathrm{TcO}_{2}$ that precipitated.

* The information contained in this article was developed during the course of work under Contract No. DE-AC09-76SR00001 with the U. S. Department of Energy 
Glass for this study was prepared by adding Tc-99 to SRP 165 Black Frit supplied by Ferro Corporation, Cleveland, Ohio. This frit is a borosilicate glass containing simulated SRP nuclear waste. Its composition is given in Table I. To achieve the desired activity level of Tc-99 in the glass, exactly $70 \mu \mathrm{Ci}$ of Tc-99 in carrier free $\mathrm{NH}_{4} \mathrm{TcO}_{4}$ solution was added per gram of dry glass frit. With no Tc-99 volatility from the melt, the specific activity of the final glass would be 35 times greater than that forecast for actual DWPF waste glass[4].

\section{Table I. Black Frit Simulated DWPE Glass Composition}

\begin{tabular}{cccc} 
Component & Weight \% & Component & Weight \% \\
\cline { 2 - 4 } $\mathrm{SiO}_{2}$ & 54.1 & $\mathrm{CaO}$ & 1.5 \\
$\mathrm{Fe}_{2} \mathrm{O}_{3}$ & 12.3 & $\mathrm{NiO}$ & 0.9 \\
$\mathrm{Na}_{2} \mathrm{O}$ & 10.3 & $\mathrm{MgO}$ & 0.8 \\
$\mathrm{~B}_{2} \mathrm{O}_{3}$ & 6.8 & $\mathrm{ZOO}$ & 1.2 \\
$\mathrm{Li}_{2} \mathrm{O}$ & 4.7 & $\mathrm{~F}$ & 0.06 \\
$\mathrm{Al}_{2} \mathrm{O}_{3}$ & 4.1 & $\mathrm{Cl}$ & 0.05 \\
$\mathrm{MnO}_{2}$ & 2.9 & $\mathrm{~Pb}$ & 0.05
\end{tabular}

Two batches of glass were made. The first was prepared under ambient oxidizing conditions and the second under reducing conditions. To prepare the glass under oxidizing conditions, the Tc-99 frit slurry was carefully dried at $90^{\circ} \mathrm{C}$ and placed in a Pt-Au crucible. The crucible was placed in an electrically heated furnace and the temperature slowly increased to $1150^{\circ} \mathrm{C}$. The temperature was held there for 3 hours. The atmosphere inside the furnace was not controlled during melting. The molten glass was poured into two $0.75^{\prime \prime}$ OD by 3 " long flat-bottom 304L SS test tubes. The tubes of molten glass were immediately placed into a preheated annealing furnace for 1 hour at $500^{\circ} \mathrm{C}$. The furnace was then cooled to room temperature. Each tube was sectioned into $\sim 5 \mathrm{~mm}$ thick disks using a high-speed $\sim 200$ grit carborundum saw with water as the cutting fluid. Approximately 30 disks were obtained. The disks were leached without further surface polishing.

To prepare the glass under reducing conditions, a second batch of Tc-99 doped frit was melted in the furnace. Reducing conditions were achieved by adding $0.5 \mathrm{wt} \%$ graphite to the dried Tc-99 frit mixture. The molten glass was poured into graphite molds ( 0.5 "ID by $\approx 3^{\prime \prime}$ tall) to ensure that reducing conditions were maintained while the glass was solidifying. The solidified glass was removed as quickly as possible from these molds and placed in an annealing furnance at $500^{\circ} \mathrm{C}$ for 1 hour. The furnace was then cooled to room temperature. Two cylinders of glass were obtained. Samples for leaching were then obtained as described above.

\section{Leaching Procedures}

The MCC-1 leaching procedure [5] at $90^{\circ} \mathrm{C}$ was followed in this study with three modifications. First, the glass disks were placed in 304L stainless steel holders rather than Teflon $^{T M}$. This modification was made because of effects of radiation on Teflon ${ }^{T M}$ to produce HF which increases leaching [6]. Teflon ${ }^{\mathrm{TM}}$ vessels could be used since they were efficiently shielded from the beta radiation from Tc- 99 by the leachate. The second modification was that the leachates were simulated groundwaters rather than deionized water. Last, the SA/V ratio was $100 \mathrm{~m}^{-1}$ rather than $10 \mathrm{~m}^{-1}$ as prescribed by the MCC-1 procedure. These latter two modifications were made to more closely simulate geologic repository conditions.

After each leach test, the Teflon ${ }^{\mathrm{TM}}$ vesel was removed from the $90^{\circ} \mathrm{C}$ oven and allowed to cool. After it was weighed to determine the final volume of solution, it was opened and the glass and basket were removed. Two aliquots of the leachate were removed for pH determination. Other aliquots were removed for cation and Tc-99 measurements. The leachate was then acidified and resampled. In the tests with brine, many solids were present after the 
leach tests. These appeared to be $\mathrm{Fe}(\mathrm{OH})_{3}$ which probably resulted from corrosion of the stainless steel baskets. These solutions were not sampled prior to acidification. Cation analyses were perfomed by ICP and Tc-99 was determined by calibrated organic liquid scintillation counting of the Tc- 99 beta particles.

Leach results are presented in terms of normalized mass loss. This quantity is given by $N L_{i}=N_{i} /\left(S A \times X_{i}\right)$ where $N L_{i}$ is the mass of glass dissolved per unit area based on species $i$. $\mathrm{N}_{i}$ is the amount of species $i$ measured, $S A$ is the surface area of the glass, and $X_{i}$ is the mass fraction of $i$ in the glass based on its composition.

\section{RESULTS AND DISCUSSION}

\section{Tc-99 Content of the Glass}

To determine the Tc- 99 content of the final glasses, three disks of glass from both types of glass were chosen at random to be dissolved. The steel band around the glass disks prepared under oxidizing conditions was removed. Each of the disks was crushed and known weights of each were dissolved separately in concentrated HF at room temperature for several days. Room temperature was chosen to decrease the possibility of losing Tc-99 due to its volatility. The final solutions were diluted and duplicate aliquots were removed for Tc-99 determination by calibrated organic liquid scintillation counting. Results (Table II) indicate that each slice from each type of glass had the same Tc-99 content within experimental error. This suggests that the Tc-99 was probably distributed homogeneously throughout each glass. The average of the values given in Table II for each glass was used in calculating the normalized mass losses in the leach tests. Based on the amount of Tc-99 added to each glass, $70 \mu \mathrm{Ci} / \mathrm{g}$, and the amount remaining (Table II), it is apparent that sizable fractions of the Tc-99 volatilized during the melting of the glasses.

\section{Table II. Tc-99 Content of the Doped Black Frit Simulated DWPF Glass ${ }^{2}$}

Sample

Number

1
2
3
Specific Activity (4Ci/g glass)

Glass Prepared
under Oxidizing Conditions

$26.1 \pm 0.1$

$25.9 \pm 0.3$

$26.2 \pm 0.2$

\author{
Glass Prepared \\ under Reduced Conditions
}

$42.2 \pm 0.2$

$42.6 \pm 0.1$

$44.7 \pm 0.1$

$\bar{a}$ The specific activity before melting was $70 \mu \mathrm{Ci} / \mathrm{g}$. Glass samples were dissolved in conc. HF. Results are averages of duplicate analyses of aliquots of the final solutions.

\section{Tc-99 Volatilization During Melting}

Technetium volatilized from the molten glass at $1150^{\circ} \mathrm{C}$. Melting under oxidizing conditions resulted in the loss of $63 \%$ of the Tc-99 from the melt. Under reducing conditions in the melt, $\approx 40 \%$ of the Tc- 99 was volatilized. Apparently, volatilization is affected by redox conditions in the melt. Less Tc-99 was volatilized from the melt under reducing conditions, probably because $\mathrm{Tc}$ was reduced in the melt from its initial state of +7 to +4 . The +4 oxide $\mathrm{TcO}_{2}$ is less volatile than the +7 oxide, $\mathrm{Tc}_{2} \mathrm{O}_{7}$ [7]. Tests are being planned to measure volatilization of Tc-99 from a continuously fed joule-heated melter in the Shielded Cells of SRL. It is expected that volatilization will be less because of the cold cap on the melt in this type of melting and the reducing conditions in the melt.

\section{Leaching in Tuff Groundwater}

The tuff rock formation in Yucca Mountain, Nevada is being investigated as a possible location for the permanent disposal of high level nuclear waste. The tuff groundwater used in 
these leach tests was fumished by Lawrence Livermore National Laboratory and was obtained from the J-13 well located in this formation. Principal components are $\mathrm{Ca}, 14 \mathrm{ppm}, \mathrm{Si}$, 27ppm, and $\mathrm{Na}, 42 \mathrm{ppm} \mathrm{[8].} \mathrm{Principal} \mathrm{anions} \mathrm{are} \mathrm{HCO}_{3}{ }^{-}$and $\mathrm{SO}_{4}=$ [8].

Final pH values and normalized mass losses are shown in Table III for leach tests in J-13 water with the glass prepared under oxidizing conditions. Identical results were obtained for the glass prepared under reducing conditions; thus, those results are not presented here. Table III shows that the $\mathrm{pH}$ of the solution increased as the leach time increased. This has been observed before[9] in tests with J-13 water and results from alkali from the glass exchanging with $\mathrm{H}^{+}$ions in the leachate. The normalized mass losses for the elements were calculated after their measured concentrations were corrected for the concentration of that respective element in the J-13 water before the test (Table III). The data indicate that the mass losses based on Tc-99 are comparable to those based on B, Li, or Na. Tc-99 does not leach extraordinarily fast from the glass as suggested by earlier data [1]. For these elements, results were identical for acidified and nonacidified leachates indicating that these species were soluble in the leachate. The normalized mass losses based on Si are low because the groundwater is already partially saturated with a Si compound. Acidification also had no effect on the Si concentration. For $\mathrm{Al}, \mathrm{Fe}$, and $\mathrm{Mn}$, the acidified results were always higher, indicating that these elements has sorbed on the leach vessel or had precipitated in the leachates even though solids were not visibly present. Normalized mass losses based on $\mathrm{Ca}$ and $\mathrm{Mg}$ were negative because the final concentration after a leach test was lower than the initial. This has also been observed previously [9] and is due to the precipitaion of $\mathrm{Ca}$ and $\mathrm{Mg}$ induced by the increased temperature during the test $[10]$.

Table III. Final oH Values and Normalized Mass Losses for Tc-99 Glass $^{\mathrm{a}}$ in Tuff $(\mathrm{J}-13)$ Groundwater. Initial $\mathrm{pH}=7.4^{\mathrm{b}}$

\begin{tabular}{|c|c|c|c|c|c|c|c|c|c|c|c|}
\hline \multirow{2}{*}{$\begin{array}{l}\text { Leach } \\
\text { Time, } \\
\text { Days }\end{array}$} & \multirow{2}{*}{$\begin{array}{l}\text { Final } \\
\mathrm{pH} \\
\text { Values } \\
\end{array}$} & \multicolumn{10}{|c|}{ Normalized Mass Losses, $\mathrm{g} / \mathrm{m}^{2}$} \\
\hline & & Tc-99 & B & $\underline{\mathrm{Na}}$ & $\mathbf{L i}$ & $\underline{\mathrm{Si}}$ & $\mathrm{Al}^{\mathrm{C}}$ & $\mathrm{Ee}^{\mathrm{C}}$ & $\mathrm{Ca}^{\mathrm{c}}$ & $\mathrm{Mn}^{\mathrm{C}}$ & $\mathrm{Mgc}$ \\
\hline $\begin{array}{c}3 \\
7 \\
14 \\
28 \\
56 \\
90\end{array}$ & $\begin{array}{l}8.3 \\
8.5 \\
8.7 \\
8.8 \\
9.4 \\
9.3\end{array}$ & $\begin{array}{l}3.3 \\
3.1 \\
3.8 \\
4.6 \\
5.5 \\
6.8\end{array}$ & $\begin{array}{l}1.9 \\
1.6 \\
3.5 \\
3.7 \\
4.6 \\
6.4\end{array}$ & $\begin{array}{l}2.9 \\
2.3 \\
4.4 \\
5.2 \\
5.7 \\
8.6\end{array}$ & $\begin{array}{l}2.8 \\
2.7 \\
4.8 \\
5.8 \\
7.4 \\
11\end{array}$ & $\begin{array}{l}0.65 \\
0.6 \\
1.5 \\
1.4 \\
1.6 \\
2.2\end{array}$ & $\begin{array}{l}0.3 \\
0.1 \\
1.1 \\
0.5 \\
1.3 \\
.02\end{array}$ & $\begin{array}{l}0.4 \\
0 \\
0.6 \\
0.6 \\
1.4 \\
.4\end{array}$ & $\begin{array}{l}-7.5 \\
-7.8 \\
-15 \\
-2 \\
-17 \\
-10\end{array}$ & $\begin{array}{l}0.14 \\
1.8 \\
0.5 \\
0.4 \\
1.2 \\
.4\end{array}$ & $\begin{array}{l}-7 \\
-2 \\
-6 \\
1 \\
-2.1 \\
-3\end{array}$ \\
\hline
\end{tabular}

a Glass prepared under oxidizing conditions.

b $\mathrm{T}=90^{\circ} \mathrm{C}, \mathrm{SA} / \mathrm{V}=100 \mathrm{~m}^{-1}$.

c Determined from acidified leachates. Acidification did not affect other results.

For Tc-99 and the major elements in the glass, $\mathrm{Li}, \mathrm{Na}, \mathrm{B}$, and Si three different release rate trends are observed. This is shown graphically in Figure 1 . Li and $\mathrm{Na}$ leach faster than $\mathrm{B}$ which leaches faster than Si. The same trends were observed for the glass made under reduced conditions. With both glasses, Tc-99 leaches from the glass at a rate approximately equal to that for $\mathrm{B}$, a glass-matrix-forming element in the glass. Normalized mass losses for $\mathrm{Na}$ and $\mathrm{Li}$ are higher probably because of an ion exchange mechanism affecting their release.

Bazan at LLNL has leached a Tc-99 containing glass in tuff groundwater [11]. The glass he used was ATM-8 glass which has a composition similar PNL 76-68. In agreement with the data presented here, he found that the normalized mass loss based on Tc-99 was closely identical to that for $\mathrm{B}$.

\section{Leaching in Simulated Salt Groundwater}

The bedded salt deposit in the Permian Basin in Texas is being investigated as a possible location for a high level nuclear waste repository. The brine used in this study was WIPP Brine A, which is primarily $\mathrm{MgCl}_{2}, 3 \times 10^{5} \mathrm{ppm}, \mathrm{NaCl}, 1 \times 10^{5} \mathrm{ppm}$, and $\mathrm{KCl}, 6 \times 10^{4}$ ppm.[12]. A detailed composition is given in Reference 12. It is a generic brine representative 


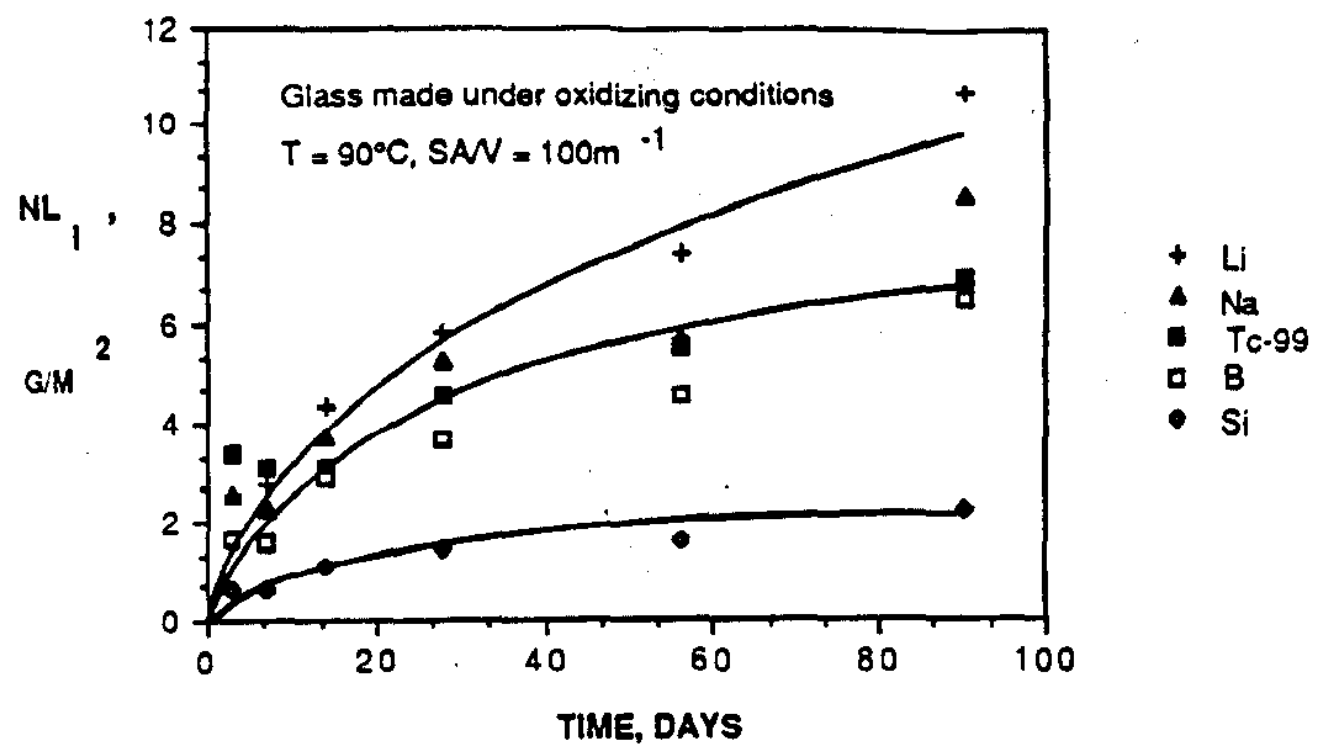

Figure 1. Normalized Mass Losses for Tc-99 Doped Glass in Tuff Groundwater.

Lines indicate release rate trends for $\mathrm{Li}$ and $\mathrm{Na}, \mathrm{B}$ and $\mathrm{Tc}-99$, and $\mathrm{Si}$, respectively.

of one that results when groundwater percolates through a potash zone that overlays the bedded salt deposit. It composition is based on brines found in the WIPP site at New Mexico.

Final $\mathrm{pH}$ values and normalized mass losses for $\mathrm{Tc}-99, \mathrm{Si}$, and $\mathrm{Li}$ for the leach tests in brine are shown in Table IV for the glass prepared under reducing conditions. Again, identical results were obtained for the glass prepared under oxidizing condition, thus they are not presented here. Because of the high ionic strength of the brine, the $\mathrm{pH}$ values in Table IV are relative and do not indicate the actual activity (concentration) of $\mathrm{H}^{+}$ions in the brine. It does appear that $\mathrm{pH}$ changes during the leaching were not significant. Normalized mass losses could only be measured for $\mathrm{Tc}-99, \mathrm{Si}$, and $\mathrm{Li}$, because concentrations of other elements in the original brine were too high to allow accurate determinations of the amount of that element that had leached from the glass. Because particulates were present in the final leachates from corrosion of the stainless steel basket, only the results of acidified leachates were used. As indicated in Table IV, Tc-99 leaches at a rate similar to Si; thus, Tc-99 does not leach faster from the glass than a glass matrix forming element. The rate based on $\mathrm{Li}$ is higher, probably due to increased ion exchange because of the high $\mathrm{Na}$ concentrations in the leachate. Time dependence of the leaching for the glass prepared under reducing conditions is shown in Figure 2. The same dependence was seen with the glass prepared under oxidizing conditions.

Table IV Final oH Values and Normalized Mass Losses for Tc-99 Glass $^{2}$ in WIPP Brine $A$. Initial $D H=6.5^{\circ}$

\begin{tabular}{|c|c|c|c|c|}
\hline \multirow{2}{*}{$\begin{array}{l}\text { Leach } \\
\text { Time, } \\
\text { Days }\end{array}$} & \multirow{2}{*}{$\begin{array}{l}\text { Final } \\
\mathrm{pH} \\
\text { Values }\end{array}$} & \multicolumn{3}{|c|}{ Normalized Mass Loss. $\mathrm{g} / \mathrm{m}^{2} \mathrm{~d}$} \\
\hline & & Tc-99 & Si & $\mathrm{Li}$ \\
\hline $\begin{array}{c}3 \\
7 \\
14 \\
28 \\
56 \\
84\end{array}$ & $\begin{array}{l}6.1 \\
7.0 \\
6.7 \\
7.0 \\
7.1 \\
6.5\end{array}$ & $\begin{array}{l}2.9 \\
1.5 \\
1.5 \\
2.1 \\
1.7 \\
3.6\end{array}$ & $\begin{array}{l}0.64 \\
1.2 \\
2.3 \\
2.1 \\
6.1 \\
5.8\end{array}$ & $\begin{array}{l}2.8 \\
2.7 \\
7.2 \\
3.0 \\
14.1 \\
19\end{array}$ \\
\hline
\end{tabular}




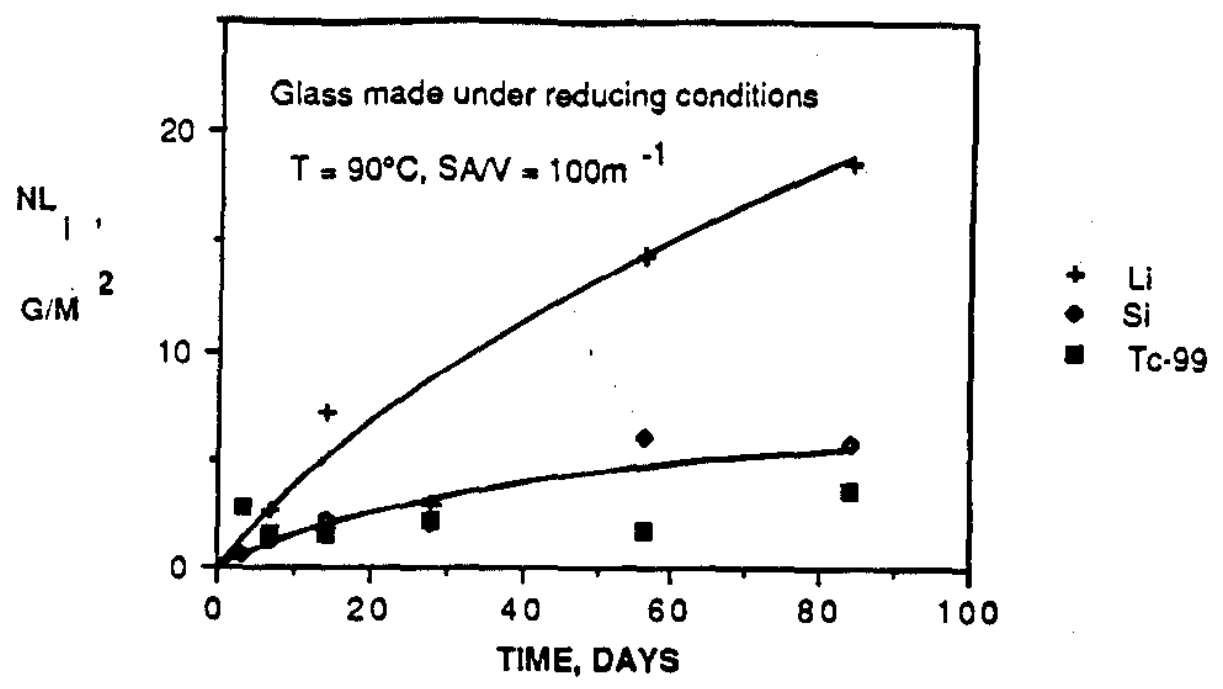

Figure 2. Normalized Mass Losses for Tc.99 Doped Glass in WIPP Brine A. Lines indicate release rate trends for $\mathrm{Li}$ and for Si and Tc-99, respectively.

McGrail at PNL has leached a Tc-99 doped simulated DWPF glass in a low Mg brine (Permian Basin Brine 1) at $90^{\circ} \mathrm{C} \mathrm{[3]} \mathrm{but} \mathrm{did} \mathrm{not} \mathrm{directly} \mathrm{calculate} \mathrm{a} \mathrm{normalized} \mathrm{mass} \mathrm{loss} \mathrm{for} \mathrm{the}$ release based on Tc-99. From his data at 100 days, we calculated a normalized mass loss of $1.9 \mathrm{~g} / \mathrm{m}^{2}$. The agreement between this result and those presented here is satisfactory. His tests were at a SA/V ratio of $1000 \mathrm{~m}^{-1}$ which is $10 \mathrm{X}$ higher than that used here. For a comparable time, this higher $S A / V$ would cause a lower release rate than that observed at $100 \mathrm{~m}^{-1}$.

\section{Effect of Reducing Conditions on Leaching Tc-99}

These tests were performed with tuff groundwater and were specifically designed to determine if reducing conditions decreased the leaching of Tc- 99 from the glass or merely caused a decrease in the solubility of Tc-99 in the leachate. For these tests, the tuff groundwater was made reducing by the addition of a $\mathrm{Zn} / \mathrm{Hg}$ amalgam. Results for 3-, 7-, and 21-day tests are shown in Table $V$. The 3 and 7 day leachates were sampled before and after acidifying and filtering. In the 21 -day test, the final leachate had so many solids that a nonacidified, unfiltered sample could not be obtained. Data in Table $V$ indicate a very large increase in $\mathrm{pH}$ during leaching compared to the $\mathrm{pH}$ changes in tests in oxidizing tuff groundwater (see Table III). This increase is due to the reaction of $\mathrm{Zn}$ with the water to produce $\mathrm{OH}^{-}$ions as well as the reducing conditions. This increased $\mathrm{pH}$ caused a large increase in leaching as indicated by the extremely high normalized mass losses for $\mathrm{Na}, \mathrm{B}$, and $\mathrm{Li}$, especially in the case of the 21-day test. However, even with these large leach rates, the normalized mass loss based on Tc-99 in the unfiltered solutions did not increase higher than it was under oxidizing conditions (Table III). Also, it did not increase with time as did the mass loss based on B. The high rate for B indicates that the glass was dissolving to a considerable extent. In the filtered leachates, the normalized mass losses for Tc-99 were very low, indicating low Tc-99 concentrations in the solutions. This suggests that Tc-99 had precipitated from the solution. 


\section{Table V Final pH Values and Normalized Mass Losses for Tc-99 Glass \\ Leached Under Reducing Conditions in Tuff Groundwater. Initial $\mathrm{Ph}=7.4^{\mathrm{a}}$}

\begin{tabular}{|c|c|c|c|c|c|c|c|}
\hline \multirow{2}{*}{$\begin{array}{l}\text { Leach } \\
\text { Time, } \\
\text { Days }\end{array}$} & \multirow{2}{*}{$\begin{array}{l}\text { Leachate } \\
\text { Sample }\end{array}$} & \multirow{2}{*}{$\begin{array}{c}\text { Final } \\
\mathrm{pH} \\
\text { Value }\end{array}$} & \multicolumn{5}{|c|}{ Normalized Mass Loss $\left(\mathrm{g} / \mathrm{m}^{2}\right)$} \\
\hline & & & Tc-99 & $\underline{\mathrm{Si}}$ & $\mathrm{Na}$ & $\underline{B}$ & $\mathrm{Li}$ \\
\hline $\begin{array}{l}3 \\
3 \\
7 \\
7 \\
21\end{array}$ & $\begin{array}{l}\text { Unfiltered } \\
\text { Filtered }^{b} \\
\text { Unfiltered } \\
\text { Filteredb } \\
\text { Filtered }\end{array}$ & $\begin{array}{l}10.0 \\
-- \\
11.3 \\
-\ddot{12.6}\end{array}$ & $\begin{array}{l}1.70 \\
0.15 \\
1.5 \\
0.26 \\
.015\end{array}$ & $\begin{array}{l}-- \\
0.04 \\
1.3 \\
0.99 \\
1.5\end{array}$ & $\begin{array}{l}-. \\
20.6 \\
30.8 \\
30.8 \\
166\end{array}$ & $\begin{array}{l}- \\
4.49 \\
31.0 \\
28.6 \\
149\end{array}$ & $\begin{array}{l}-- \\
5.18 \\
29.1 \\
26.9 \\
130\end{array}$ \\
\hline
\end{tabular}

$\overline{\mathrm{a}} \mathrm{T}=90^{\circ} \mathrm{C}, \mathrm{SA} / \mathrm{V}=100 \mathrm{~m}^{-1}$. Reducing conditions achieved by adding $5 \% \mathrm{Zn}, 95 \% \mathrm{Hg}$ $\mathrm{b}$ Leachate filtered through a $0.45 \mu \mathrm{m}$ filter.

The results in Table $\mathrm{V}$ indicate that, even though the glass is dissolving (based on the $\mathrm{B}$ results) and Tc-99 is being released to the solution, the Tc-99 concentration is low-presumably due to its reduction and precipitation. Thus, reducing conditions are effective in lowering the concentration of Tc-99 even if the glass is dissolving. Other studies $[13,14]$ have shown that reducing conditions such as those that will be present in a granite or basalt repository decrease leach rates of the glass matrix elements and the alkali elements less than a factor of 2 based on $\mathrm{B}, \mathrm{Si}$, or $\mathrm{Li}$. The significant decreases, greater than a factors of 10 , observed for the redox active elements [1-3] such as Tc-99 must be due to solubility effects rather then an increase in the durability of the glass.

\section{CONCLUSIONS}

Data presented in this paper support the following conclusions:

1. Borosilicate glass similar to that which will be produced by the DWPF at SRP immobilizes Tc-99 in a manner similar to that for B. Tc-99 does not leach faster from the glass than B in tuff groundwater or $\mathrm{Si}$ in a brine. These elements are major matrix-forming elements in the glass.

2. In leach tests under reducing conditions, the low leach rates observed for Tc-99 are due to its low solubility and not due to any increased durability of the glass.

\section{References}

1. D.G. Coles and M.J. Apted "The Behavior of ${ }^{99} \mathrm{Tc}$ in Doped-Glass/Basalt Hydrothermal Interaction Tests," Scientific Basis for Nuclear Waste Management VII, edited by G.L. McVay (Elsevier Science Publishers, New York, 1984), p 129.

2. W. B. White "Dissolution of Specific Radionuclides," in Einal Report of the Defense High Level Waste Leaching Mechanisms Program, USDOE Report PNL-5157, Pacific Northwest Laboratory, Richland, WA, 4.1-4.9 (1984).

3. B. P. McGrail "Waste Package Component Interactions with Savannah River Plant Defense Waste Glass in a Low-Magnesium Brine," Nuclear Technology, 75, 165-178 (1986).

4. R. G. Baxter "Description of Defense Waste Processing Facility Reference Waste Form and Canister," Savannah River Laboratory, Aiken, SC, USDOE Report DP-1606, Rev 1, (1983). 
5. Nuclear Waste Materials Handbook - Waste Form Test Methods, MCC-1P Static Test, DOE/TIC-11400, Pacific Northwest Laboratory, Richland WA (1981).

6. N. E. Bibler "Leaching Fully Radioactive SRP Nuclear Waste Glass in Tuff Groundwater in Stainless Steel Vessels," Advances in Cermanics, 60, 619-626 (American Ceramic Society, Columbus, Ohio 1986).

7. J. A. Rard "Critical Review of the Chemistry and Thermodynamics of Technetium and Some of its Inorganic Compounds and Aqueous Species," USDOE Report UCRL-53440, Lawrence Livermore National Laboratory, Livermore, CA (1983).

8. W. E. Glassley, "Reference Waste Package Environment Report," USDOE Report UCRL-53726, Lawrence Livermore National Laboratory, Livermore, CA (1986).

9. N. E. Bibler, G. G. Wicks, and V. M. Oversby "Leaching Savannah River Plant Nuclear Waste Glass in a Saturated Tuff Environment," in Scientific Basis for Nuclear Waste Management VIII, edited by C. M. Jantzen, J. A. Stone, and R. C. Ewing (Materials Research Society, Pittsburgh PA, 1984).

10. K. G. Knauss, V. M. Oversby, and T. J. Wolery, "Post Emplacement Environment of Waste Packages," Scientific Basis for Nuclear Waste Management VII, edited by G.L. McVay (Elsevier Science Publishers, New York, 1984), p 319.

11. F.Bazan and J. H. Rego "The Tuff Reaction Vessel Experiment," USDOE Report UCRL-53735, Lawrence Livermore National Laboratory, Livermore CA (1986).

12. M. A. Molecke "A Comparison of Brines Relevant to Nuclear Waste Experimentation," USDOE Report SAND83-0516, Sandia National Laboratories, Albuquerque, NM, (1983).

13. C.M. Jantzen and G.G. Wicks "Control of Oxidation Potential for Basalt Repository Simulation Tests," in Scientific Basis for Nuclear Waste Management VIII, edited by C. M. Jantzen, J. A. Stone, and R. C. Ewing (Materials Research Society, Pittsburgh, PA, p 24-35 1985).

14. C. M. Jantzen and N. E. Bibler "The Role of Groundwater Oxidation Potentail and Radiolysis of Waste Glass Performance in Crystalline Repopsitory Environments," in Scientific Basis for Nuclear Waste Management VIII, edited by L. O. Werme (Materials Research Society, Pittsburgh, PA p. 219-230 1986). 